\title{
Waste Cooking Oil Biodiesel Use in Two Off-Road Diesel Engines
}

\author{
Jing Guo, ${ }^{1}$ Edward Peltier, ${ }^{1}$ Ray E. Carter, ${ }^{1}$ Alex J. Krejci,, 2 \\ Susan M. Stagg-Williams, ${ }^{3}$ and Christopher Depcik ${ }^{4}$ \\ ${ }^{1}$ Department of Civil, Environmental and Architectural Engineering, University of Kansas, 1530 W 15 th Street, \\ Lawrence, KS 66045, USA \\ ${ }^{2}$ Department of Physics and Astronomy, Vanderbilt University, Nashville, TN 37235, USA \\ ${ }^{3}$ Department of Chemical \& Petroleum Engineering, University of Kansas, 1530 W 15th Street, Lawrence, KS 66045, USA \\ ${ }^{4}$ Department of Mechanical Engineering, University of Kansas, 1530 W 15th Street, Lawrence, KS 66045, USA
}

Correspondence should be addressed to Edward Peltier, epeltier@ku.edu

Received 13 August 2012; Accepted 11 September 2012

Academic Editors: E. R. Bandala and O. Ozgener

Copyright (C) 2012 Jing Guo et al. This is an open access article distributed under the Creative Commons Attribution License, which permits unrestricted use, distribution, and reproduction in any medium, provided the original work is properly cited.

\begin{abstract}
This study examines the composition and combustion performance of biodiesel produced from waste cooking oil. Six fuel batches produced from waste oil used in dining-hall fryers were examined to determine their physical and chemical properties, including their elemental and fatty acid methyl ester composition. Oleic and linoleic methyl esters accounted for more than $70 \%$ of the fuel composition, while the oxygen content averaged $10.2 \%$ by weight. Exhaust emissions were monitored for 5-100\% biodiesel blends using two off-road engines: a 2007 Yanmar diesel generator and a 1993 John Deere front mower. Increasing biodiesel content resulted in reduced emissions of partial combustion products from the diesel generator but a rise in $\mathrm{NO}_{x}$, with the greatest changes occurring between 5 and $20 \%$ biodiesel content. For the riding mower, biodiesel content up to $50 \%$ had little effect on emissions, while $\mathrm{NO}_{x}$ and total hydrocarbon emissions decreased with $100 \%$ biodiesel. The difference in $\mathrm{NO}_{x}$ emissions is attributed to the two different fuel injection control designs used in the two engines. These results indicate that the effects of biodiesel use on nonroad engine exhaust emissions may be substantially lower in older engines optimized for performance over emissions control.
\end{abstract}

\section{Introduction}

Rising fuel costs and energy demands, combined with growing concern over greenhouse gas emissions, have led to increased interest in the use of renewable fuels to help meet increasing worldwide fuel demand and reduce atmospheric $\mathrm{CO}_{2}$ emissions from transportation sources [1-3]. Biodiesel is an oxygenated diesel fuel composed primarily of fatty acid methyl esters that can be produced from a variety of vegetable oils and animal fats [4]. It can be used directly in existing diesel engines, either as a fuel replacement or as an additive to improve combustion processes [5]. In addition, biodiesel fuels may help to reduce emissions of some toxic air pollutants $[6,7]$.

Biodiesel can be produced from a range of vegetable oils and animal fats. The use of soybean oil and other high-quality food-grade vegetable oils presents economic difficulties because of competition with use for food products. One more economically feasible source for biodiesel is waste cooking or frying oils, also known as yellow grease. As a waste product, used cooking oil is a potentially cheaper feedstock than edible vegetable oils [8], and does not directly compete with the growth of food crops. Estimates for potential biodiesel production from waste cooking oil in the United States range from 100 to 200 million gallons per year, although recent production levels from these sources are only around a tenth of this amount $[9,10]$. As with most other vegetable-oil-based fuels, waste cooking oil (WCO) biodiesel has a higher viscosity, cetane number, and density than conventional diesel [11], but it can meet existing fuel property standards [12].

The composition of WCO biodiesel varies somewhat depending on the oil feedstock and the fuel production process. Most vegetable oil feedstocks consist primarily of $\mathrm{C}_{16}$ and $\mathrm{C}_{18}$ fatty acids, but can also include smaller contributions from other $\mathrm{C}_{8}$ to $\mathrm{C}_{22}$ compounds [13]. In addition to differences in cooking oil stocks, variations in frying temperatures and times can affect the composition of the final fuel. Several studies have identified oleic and linoleic acid as the predominant fatty acid methyl esters present in WCO 
biodiesel $[14,15]$. In a study of used cooking oils, however, Knothe and Steidley [16] observed high variability in WCO fatty acid composition from different restaurants and between batches at the same location, which could result in similar variability in the biodiesel.

Several comprehensive reviews of the existing literature have concluded that biodiesel use will generally reduce exhaust emissions of particulate matter, total hydrocarbons, and carbon monoxide $[6,7]$. Published experiments using WCO biodiesel are generally in line with these trends [1720]. Di et al. [21] observed a decrease in total hydrocarbon (THC) emissions in blends of WCO biodiesel with ultralow sulfur diesel (ULSD), with the greatest reductions (50\%) achieved with pure biodiesel. However, Lin et al. [22] found that a $20 \%$ blend of waste cooking oil biodiesel and conventional diesel produced lower carbon monoxide (CO) emissions than either pure fuel.

The effects of WCO biodiesel on emissions of nitrogen oxides $\left(\mathrm{NO}_{x}\right)$ are less predictable. Several studies have reported reductions in total $\mathrm{NO}_{x}$ emissions for pure WCO biodiesel compared to number 2 diesel $[17,19]$, while others have reported increases [18] or no substantial effect [23]. Di et al. [21] and Lin et al. [22] observed increases in $\mathrm{NO}_{x}$ emissions when WCO biodiesel fuels were blended with ultralow sulfur diesel and premium diesel, respectively. Dorado et al. [20] observed different results based on $\mathrm{NO}_{x}$ speciation, with nitric oxide $(\mathrm{NO})$ concentrations decreasing by $37 \%$ but nitrogen dioxide $\left(\mathrm{NO}_{2}\right)$ concentration increasing by up to $81 \%$. Some of this variation between studies may be due to the greater sensitivity of $\mathrm{NO}_{x}$ emissions to engine combustion conditions [24]. Additionally, differences in the chemical properties and cetane number of WCO biodiesel compared to petroleum diesel fuel will influence injection timing and subsequent premixed and diffusion burn characteristics during combustion, all of which can affect $\mathrm{NO}_{x}$ production [25-28].

In the mid 1990s, U. S. EPA began implementing emissions standards for off-road diesel engines that established maximum permitted levels for $\mathrm{CO}, \mathrm{NO}_{x}$, and hydrocarbon emissions [29]. These standards were phased in using a series of progressively stricter emissions requirements, or tiers. Initial application of Tier 1 standards occurred from 1996-2000 (depending on engine size), with Tier 2 and Tier 3 regulations going into effect from 2001-2006 and 20062008 , respectively. As these regulations apply only to newly built engines, older agricultural and construction equipment built before 1996 are not subject to these controls. In addition, stationary diesel engines were not covered by these regulations until 2007. As off-road equipment may have a lifespan of several decades or more, diesel engines currently in use are subject to a wide range of emissions regulations, ranging from no controls for older engines to strict Tier 4 standards for the newest equipment.

One particular area of concern for off-road equipment is emissions produced during idling. Since idling engine speed is relatively low, and only a small amount of fuel is added in order to maintain engine crankshaft revolution, combustion efficiency drops significantly. This results in higher hydrocarbon emissions and partial combustion products that are hazardous to the environment and the health of the user [30]. In developing representative test cycles for off-road engines, Graham et al. assigned a weighting factor of $15 \%$ to account for idling in a weed trimmer activity profile [31]. The ISO 8-Mode Cycle for steady state testing of engines weighs idle similarly at $15 \%$ [32].

The current study examines biodiesel produced from waste cooking oil feedstocks at the University of Kansas using a small-scale batch reaction process. Multiple batches of WCO biodiesel were analyzed to determine batch-to-batch variation in physical and chemical properties. One batch of the WCO biodiesel was then blended with number 2 diesel to create fuels with $5-100 \%$ biodiesel by volume. These fuels were used to power two nonroad engines under idling conditions. Exhaust emissions were analyzed to determine concentrations of $\mathrm{CO}_{2}, \mathrm{CO}, \mathrm{NO}_{x}\left(\mathrm{NO}+\mathrm{NO}_{2}\right)$, and THC. The results are used to evaluate the suitability of WCO biodiesel blends for related off-road applications and to assess the relative importance of fuel makeup and engine operations on pollutant emissions.

\section{Experimental}

2.1. Fuel. Biodiesel used in this study was produced by the University of Kansas Biodiesel Initiative, utilizing used cooking oil obtained from the University of Kansas dining halls and local restaurants. This used oil was processed to biodiesel in an on-campus pilot scale facility by conversion of the triglyceride fats to fatty acid methyl esters via base-catalyzed transesterification. Each batch of fuel produced was tested for compliance with ASTM standards for density, viscosity, and flash point. Samples from six biodiesel batches produced in 2009 and 2010 were analyzed to determine their hydrocarbon composition. For the emissions experiments, one batch of WCO biodiesel was blended with number 2 petroleum diesel fuel purchased commercially by the KU Maintenance and Operations Department. The fuels were mixed by hand to create five gallons each of $5 \%, 25 \%, 50 \%$, and $75 \%$ by volume biodiesel blends (identified in this paper as B5, B20, B50 and $\mathrm{B} 75$ fuels, resp.). The blended fuels were used in the engine tests within ten days after mixing.

2.2. Fuel Composition Analysis. An Agilent 6890 gas chromatograph coupled with an Agilent 5973N mass spectrometer (GC-MS) was used for fatty acid methyl ester (FAME) analysis of the WCO biodiesel fuels. The chromatographic column was an HP-INNOWax Polyethylene Glycol column of $15 \mathrm{~m}$ length $\times 0.25 \mathrm{~mm}$ i.d. $\times 0.5 \mu \mathrm{m}$ film thickness. Data collection and analysis were performed with HP Chemstation software. A certified standard containing $\mathrm{C}_{8}-\mathrm{C}_{24}$ FAMEs was supplied by SUPELCO. Ethyl stearate, supplied by Sigma, was used as an internal standard.

Fuels were prepared for analysis by adding $0.1 \mathrm{~mL}$ biodiesel samples to $100 \mathrm{~mL}$ of $\mathrm{n}$-hexane. One microliter of this mixture was injected into the GC-MS, which was programmed at $120^{\circ} \mathrm{C}$ for $1 \mathrm{~min}$, then ramped at $6^{\circ} \mathrm{C} / \mathrm{min}$ to $180^{\circ} \mathrm{C}, 1.5^{\circ} \mathrm{C} / \mathrm{min}$ to $198^{\circ} \mathrm{C}, 5^{\circ} \mathrm{C} / \mathrm{min}$ to $228^{\circ} \mathrm{C}$, and then held at $228^{\circ} \mathrm{C}$ for five minutes. The total run time was 34 minutes. The injection port and transfer line were held 
at $250^{\circ} \mathrm{C}$. Samples were injected in splitless mode with helium as the carrier gas with a flow through the column of $1.4 \mathrm{~mL} / \mathrm{min}$. The mass spectrometer used electron ionization at $70 \mathrm{eV}$, with an ion source temperature of $230^{\circ} \mathrm{C}$ and quadrupole temperature of $150^{\circ} \mathrm{C}$. The electron multiplier was operated at $1482 \mathrm{~V}$, and the solvent delay was $2.5 \mathrm{~min}$.

Individual fatty acid methyl esters present in each biodiesel sample were identified based on GC retention time compared to the known FAME standard compounds and mass spectrum analysis. The response factors of each compound relative to the internal standard were then used to quantify the mass present. The mass detection limit was $0.44 \times 10^{-3} \mathrm{ng}$, as determined by analysis of diluted FAME standard solutions. Relative standard deviations (RSDs) for each fatty acid methyl ester were less than $6 \%$, giving an error of $\pm 0.6 \%$ for a component comprising $10 \%$ of the total mass. For each fuel sample, the results of this compositional analysis were used to estimate the fuel $\mathrm{H}: \mathrm{C}$ ratio and oxygen content. Samples of four of the six fuels were also sent to a commercial testing laboratory for determination of elemental carbon, hydrogen, and oxygen content using ASTM D5291 and ASTM 5622.

2.3. Test Engines. Two engines were used in these experiments: a Yanmar Model 3TN75RJ installed in a 1993 F1145 John Deere Front Mower, and a Yanmar L100V6 installed in a 2007 YDG 5500EV diesel generator. Specifications for both engines are listed in Table 1 . The generator engine uses direct injection with a mechanical fuel pump-line injector at a pressure of $19.6 \mathrm{MPa}$. The front mower engine is also direct injection, with a mechanical unit injector at the same injection pressure. The majority of the experiments were performed on the generator engine, which was purchased new and had less than 50 hours run time prior to the beginning of these experiments. The mower, which had been in service by the University of Kansas Grounds and Maintenance Division since its initial purchase in 1993, was used to provide comparative emissions data from an older engine.

2.4. Emissions Test Procedure. The Yanmar generator was located in a test cell under controlled atmospheric conditions, with an ambient temperature between 23.0 and $24.5^{\circ} \mathrm{C}$ during all tests. Five different biodiesel blends (Petroleum Diesel, B5, B20, B50, and B100) were tested in a rotating order each day for six days, ensuring that each fuel was in each position once. During the final two experiments, a sixth blend, B75, was also tested. Between each test, the gas tank was completely drained and rinsed several times with the fuel for the next test. During each test, the engine was fully warmed up for 30 minutes prior to the beginning of data collection. Emissions were then monitored for 30 minutes. All experiments were performed with the generator at zero added loading.

Biodiesel combustion experiments with the mower were performed outdoors at the University of Kansas. Ambient temperatures during the test period varied from $13.5^{\circ} \mathrm{C}$ to $28.0^{\circ} \mathrm{C}$. The variation within a given day was between 3 and $4^{\circ} \mathrm{C}$, while the largest mean temperature difference between
TABLE 1: Test engine properties.

\begin{tabular}{lcc}
\hline & Front Mower & Generator \\
\hline Manufacturer & Yanmar & Yanmar \\
Model & 3TN75RJ & L100V6-GY \\
Year & 1993 & 2007 \\
Number of cylinders. & 3 & 1 \\
Displacement, L & 0.994 & 0.435 \\
Bore, mm & 75 & 86 \\
Stroke, mm & 75 & 75 \\
Rated power, hp & 24 & 9.1 \\
Compression ratio & $17.8: 1$ & $21.2: 1$ \\
\hline
\end{tabular}

the six test days was $10^{\circ} \mathrm{C}$. Four different biodiesel blends, were used in these tests: B5, B20, B50, and B100. Since the mower had been operating on a B5 mixture for more than a year before the beginning of the experiment, no tests were performed with $100 \%$ petroleum diesel. Daily testing followed the same procedure as described above for the generator tests, except that not all fuels were tested on each day. The engine was set to idle throughout each experiment.

2.5. Emissions Collection and Analysis. The exhaust pipe from each engine was attached to a high-speed exhaust flow meter (EFM-HS; Sensors, Inc.) using one foot $(0.30 \mathrm{~m})$ of metal tubing attached to seven feet $(2.1 \mathrm{~m})$ of silicon hose connectors. Heated exhaust was pulled from the flow meter at a rate of eight $\mathrm{L} / \mathrm{min}$ and transferred by heated line to the emission analyzer. The heated line maintained the exhaust at $192^{\circ} \mathrm{C}$ to prevent water and total hydrocarbon condensation. Ambient temperature, absolute humidity, and exhaust gas temperature were continuously monitored and recorded via an external weather probe throughout each experiment.

Analysis of gas-phase exhaust constituents was carried out using a SEMTECH-DS portable emissions analyzer (Sensors, Inc.). This instrument measures $\mathrm{CO}_{2}$ and $\mathrm{CO}$ concentrations by using nondispersive infrared spectroscopy (NDIR), $\mathrm{NO}$ and $\mathrm{NO}_{2}$ by nondispersive ultraviolet spectroscopy (NDUV), and THC using a heated flame ionization detector (FID). An auxiliary electrochemical sensor provided simultaneous $\mathrm{O}_{2}$ measurements. The analyzers were calibrated at the beginning and end of each day using ambient air as the reference zero condition.

Raw concentrations were converted to fuel-specific mass emissions using the SEMTECH analytical software. This is accomplished by composing an overall carbon balance in the exhaust to estimate the total amount of fuel consumed. The calculation for the fuel-specific emissions is shown below for NO [33]:

$$
\mathrm{NO}_{\mathrm{fs}}=\left(\frac{[\mathrm{NO}]}{[\mathrm{CO}]+[\mathrm{HC}]+\left[\mathrm{CO}_{2}\right]_{\mathrm{adj}}}\right) *\left(\frac{\mathrm{MW}_{\mathrm{NO}}}{\mathrm{MW}_{\text {fuel }}}\right),
$$

where $\mathrm{NO}_{\mathrm{fs}}$ is the fuel-specific $\mathrm{NO}$ concentration $(\mathrm{g} / \mathrm{g}$ fuel), $\left[\mathrm{CO}_{2}\right]_{\text {adj }}$ is the measured $\mathrm{CO}_{2}$ concentration minus the ambient $\mathrm{CO}_{2}$ concentration determined during calibration, $\mathrm{MW}_{\mathrm{NO}}$ and $\mathrm{MW}_{\text {fuel }}$ are the "molecular weights" of NO and 
the fuel, respectively, and all concentrations are in parts per million ( $\mathrm{ppm}$ ). $\mathrm{MW}_{\text {fuel }}$ is not a true average molecular weight of the fuel, but a value based on the formula $\mathrm{CH}_{x}$, where $x$ is the number of hydrogen atoms per atom carbon in the fuel. For the biodiesel blends used, an adjusted $\mathrm{MW}_{\text {fuel }}$ formula of $\mathrm{CH}_{x} \mathrm{O}_{y}$, where $y$ is the number of oxygen atoms per carbon atom, was used to account for the oxygen content of the fuels.

2.6. Statistical Analysis. An analysis of variance (ANOVA) test was performed to estimate the effects of biodiesel content and other factors on the fuel-specific emissions. The investigators used a general linear model, with biodiesel percentage and the test order of the different blends as the fixed effects. Ambient temperature, exhaust temperature (measured at the exhaust flow meter and used as a surrogate for engine temperature during combustion), and absolute humidity were chosen as covariates. A Pearson correlation analysis was performed on the influence factors that were reported to be statistically significant for two or more pollutants for each engine to test for the linearity and direction of the correlation. All statistical analyses were performed using MiniTab and all variables were tested at the $95 \%$ confidence interval.

\section{Results and Discussion}

3.1. Biodiesel Composition and Properties. The waste cooking oil biodiesel consisted primarily of $\mathrm{C}_{16}$ to $\mathrm{C}_{20}$ esters, with oleic and linoleic acids accounting for at least $75 \%$ of the total mass of each sample (Table 2). The two samples analyzed in 2009 had higher concentrations of more saturated compounds, particularly palmitic acid, and an overall composition similar to used frying oils characterized by Mittelbach and Gangl [15]. The four samples from 2010 had higher concentrations of less saturated $\mathrm{C}_{18}$ FAMEs and a greater proportion of longer chain compounds. These differences could be due either to differences in cooking time and temperature, which can increase the saturated FAME content [16], or to variations in the cooking oil feedstocks. Both peanut and canola oils are used at the locations providing the waste cooking oil for this study, with peanut oil having a higher palmitic oil content [34]. The remaining fraction, including uncharacterizable materials, was less than $6 \%$ of the total carbon for all samples. There was very little variation in the density of the six fuels, with values ranging from $873-886 \mathrm{~g} / \mathrm{L}$ and an average of $881 \pm 1.73 \mathrm{~g} / \mathrm{L}$ (an RSD of $0.5 \%$ ). The kinematic viscosity showed slightly more variation, ranging from 4.55$5.03 \mathrm{~mm}^{2} / \mathrm{s}$, with an average of $4.73 \pm 0.092 \mathrm{~mm}^{2} / \mathrm{s}$ (RSD of $4.8 \%$ ). There was no apparent correlation between fuel composition and variations in either the density or viscosity.

For the 2010 fuel samples, the bulk fuel composition results obtained from GC-MS analysis were verified by estimating the calculated $\mathrm{H}: \mathrm{C}$ ratio and fuel oxygen content based on the FAME composition of the fuel and comparing these predicted values to actual values determined by direct elemental analysis (Table 3). The estimated and total oxygen compositions are in close agreement for WCO4 and WCO5, while the $\mathrm{WCO} 3$ and WCO6 estimated values are slightly lower than the measured results due to the higher content of unquantifiable material in those two samples. Actual H: C ratios were similar to predicted values with the exception of WCO3, which had a measured $\mathrm{H}: \mathrm{C}$ ratio significantly below the value estimated from FAME analysis. This fuel also had the highest viscosity of all six fuels, suggesting either a lesscomplete transesterification reaction or the presence of nonreactable contaminant materials in the waste cooking oil used for this batch.

A single batch of the waste cooking oil biodiesel (WCO1) was used in all of the emissions experiments, in order to minimize any effects due to fuel quality variations. Table 4 lists specific properties of this fuel, as well as of the B5-B75 blends created through mixing with petroleum diesel. The $\mathrm{H}: \mathrm{C}$ ratio and oxygen content for the B100 fuel were calculated from the FAME profile for the WCO1 fuel. The $\mathrm{H}$ : $\mathrm{C}$ ratio for each blend was estimated from a linear combination of the B100 fuel and the number 2 diesel. Similarly, the oxygen content was calculated as a mixture of the two end-member fuels, with the number 2 diesel assumed to have $0 \%$ oxygen. Other properties were measured individually for each fuel blend. All measured properties met ASTM D6751 specifications. The measured viscosity of the B100 fuel $\left(4.99 \mathrm{cSt} / \mathrm{s}\right.$ at $\left.40^{\circ} \mathrm{C}\right)$ was slightly higher than would be assumed based solely on the FAME composition profile, suggesting that there were some unreacted species still present in the fuel.

3.2. $\mathrm{CO}_{2}$ Emissions. Figure 1 shows the fuel-specific emissions of $\mathrm{CO}_{2}$ from both the generator and mower engines as a function of biodiesel content. Both engines showed a consistent decrease in $\mathrm{CO}_{2}$ with increasing biodiesel content. Raw $\mathrm{CO}_{2}$ exhaust concentrations, however, did not vary significantly for either engine between the different fuels. The observed decrease in fuel-specific $\mathrm{CO}_{2}$ emissions is due to the increased oxygen content in the biodiesel fuels, which results in a higher $\mathrm{MW}_{\text {fuel }}$ value for higher biodiesel blends. At the same time, however, the energy content of a $100 \%$ biodiesel fuel is also $9-10 \%$ lower than that of petroleum diesel [6]. This will result in increased fuel consumption for the same engine power output with biodiesel blends, offsetting any decrease in $\mathrm{CO}_{2}$ emissions. In our results, fuel-specific $\mathrm{CO}_{2}$ emissions decreased by $10 \%$ and $10.5 \%$, respectively, for the generator and mower engines with $\mathrm{B} 100$, so total emissions on a power-specific basis would not show any significant change. In general, biodiesel fuels are not typically expected to have a significant effect on exhaust $\mathrm{CO}_{2}$ emission rates. Biodiesel may, however, be more carbon neutral overall because of the carbon source (biological versus fossil carbon). Determining the actual net $\mathrm{CO}_{2}$ emissions difference due to biodiesel blending requires a lifecycle emissions analysis for the specific fuel that is beyond the scope of this paper.

3.3. Generator Emissions. Figure 2 shows the average emissions for $\mathrm{CO}, \mathrm{NO}_{x}$, and total hydrocarbons (THC) from the generator for the different fuel blends. Carbon monoxide and total hydrocarbon emissions decreased by 46 and $68 \%$, respectively, between the number 2 diesel and B100 fuels. The majority of this decrease occurred between 0 and $20 \%$ biodiesel content, with further increases in biodiesel content having a much smaller incremental effect on emissions of both compounds. Total nitrogen oxides, on the other hand, 
TABLE 2: Composition (as \% weight) for six waste cooking oil biodiesel samples.

\begin{tabular}{|c|c|c|c|c|c|c|c|c|c|}
\hline Sample & $\begin{array}{c}\text { Palmitic } \\
(\mathrm{C} 16: 0)\end{array}$ & $\begin{array}{c}\text { Palmitoleic } \\
(\mathrm{C} 16: 1)\end{array}$ & $\begin{array}{c}\text { Stearic } \\
(\mathrm{C} 18: 0)\end{array}$ & $\begin{array}{c}\text { Oleic } \\
(\mathrm{C} 18: 1) \\
\end{array}$ & $\begin{array}{l}\text { Linoleic } \\
(\mathrm{C} 18: 2)\end{array}$ & $\begin{array}{c}\text { Linolenic } \\
(\mathrm{C} 18: 3)\end{array}$ & $\begin{array}{c}\text { Arachidic } \\
\text { (C20:0) }\end{array}$ & $\begin{array}{l}\text { Behenic } \\
(\mathrm{C} 22: 0)\end{array}$ & Others \\
\hline WCO1 & 12.9 & $\mathrm{n}$ & 2.4 & 54.3 & 21.4 & 5.3 & 0.7 & $\mathrm{n}$ & 3.1 \\
\hline WCO2 & 14.4 & $\mathrm{n}$ & 4.8 & 51.6 & 21.6 & 3.5 & $\mathrm{n}$ & $\mathrm{n}$ & 4.1 \\
\hline WCO3 & 7.1 & 0.4 & 3.0 & 45.2 & 25.9 & 11.5 & 0.8 & 0.4 & 5.7 \\
\hline WCO4 & 7.0 & 0.4 & 3.3 & 45.9 & 26.5 & 12.4 & 0.9 & 0.6 & 2.6 \\
\hline WCO5 & 7.2 & 0.4 & 3.3 & 46.4 & 26.2 & 12.2 & 0.9 & 0.6 & 2.8 \\
\hline WCO6 & 7.4 & 0.3 & 3.0 & 46.3 & 23.4 & 12.7 & 0.8 & 0.5 & 5.7 \\
\hline
\end{tabular}

$\mathrm{n}$ : not present at detectable levels.

TABLE 3: Measured and estimated $\mathrm{H}$ : C ratios and oxygen contents.

\begin{tabular}{|c|c|c|c|c|}
\hline \multirow{2}{*}{ Sample } & \multicolumn{2}{|c|}{$\mathrm{H}: \mathrm{C}$ Ratio } & \multicolumn{2}{|c|}{ Oxygen content ( $\%$ weight) } \\
\hline & Measured $^{\mathrm{a}}$ & Predicted & Measured $^{\mathrm{a}}$ & Predicted \\
\hline WCO 3 & 1.82 & 1.85 & 10.5 & 10.3 \\
\hline WCO 4 & 1.86 & 1.85 & 10.5 & 10.6 \\
\hline WCO 5 & 1.86 & 1.85 & 10.5 & 10.6 \\
\hline WCO 6 & 1.86 & 1.85 & 10.5 & 10.3 \\
\hline
\end{tabular}

${ }^{a}$ Uncertainties in the measured $\mathrm{H}: \mathrm{C}$ ratio and oxygen content are \pm 0.02 and $0.1 \%$, respectively.

TABLE 4: Fuel properties of biodiesel blends used in the emissions study.

\begin{tabular}{lccccc}
\hline Fuel type & $\mathrm{H}: \mathrm{C}$ & Oxygen $(\% \mathrm{wt})$ & Density $(\mathrm{g} / \mathrm{L})$ & Flash point $\left({ }^{\circ} \mathrm{C}\right)$ & Viscosity $\left(\right.$ at $\left.40^{\circ} \mathrm{C}\right)$ \\
\hline B100 & 1.87 & 10.5 & 881 & 870 & $4.99 \mathrm{cST} / \mathrm{s}$ \\
B75 & 1.85 & 7.9 & 859 & 75 & $4.17 \mathrm{cST} / \mathrm{s}$ \\
B50 & 1.84 & 5.3 & 847 & 65 & $3.47 \mathrm{cST} / \mathrm{s}$ \\
B20 & 1.81 & 2.1 & 840 & 62 & $2.81 \mathrm{cST} / \mathrm{s}$ \\
B5 & 1.80 & 0.53 & 825 & 23 & $2.61 \mathrm{cST} / \mathrm{s}$ \\
\# 2 diesel & 1.80 & 0 & & $2.17 \mathrm{cST} / \mathrm{s}$ \\
\hline
\end{tabular}

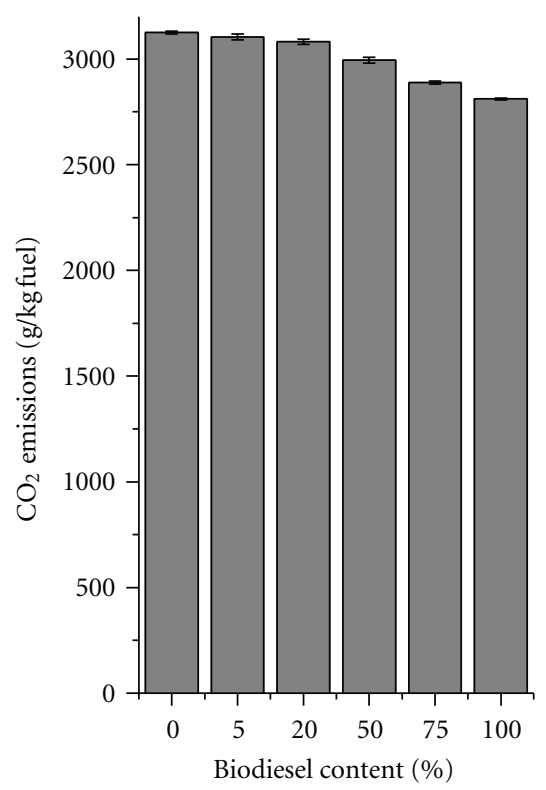

(a)

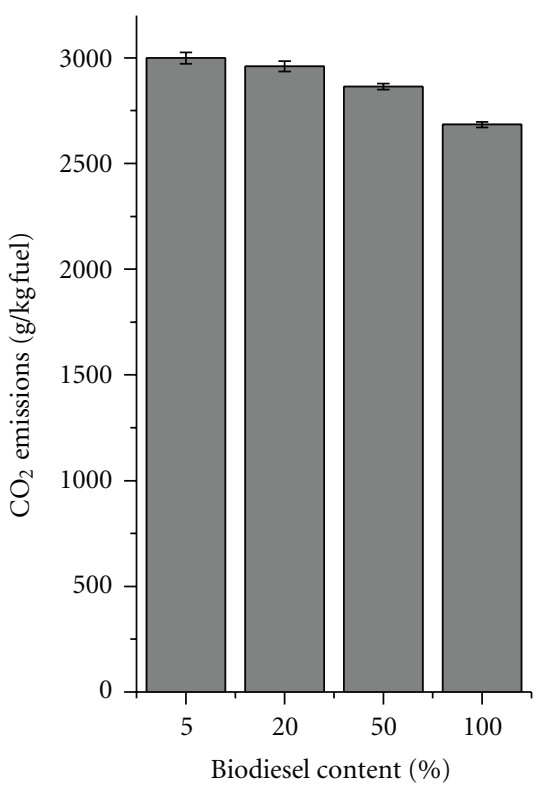

(b)

Figure 1: Fuel-specific $\mathrm{CO}_{2}$ emissions from (a) generator and (b) front mower for biodiesel blends. 
increased with greater biodiesel content, with the greatest change also occurring between the B5 and B20 blends. These results suggest that the largest impact on the combustion process is achieved at relatively low oxygen content in the fuel (1-2\%). In engines of this type, biodiesel blends at or below $5 \%$ would thus have minimal impact on exhaust emissions, while blends with more than $20 \%$ biodiesel content will all have relatively similar emissions profiles. As most engines are not optimized for idling conditions, total emissions will likely decrease at higher engine speeds, reducing the absolute differences between different fuels.

The fuel-specific emissions reported here do not account for any changes in fuel consumption rates related to the lower energy content of the biodiesel blends. This is due to the difficulty in accurately measuring output power at "no load" conditions. However, the effect of these changes can be estimated. For a $10 \%$ decrease in energy content between the petroleum diesel and the B100 fuel, we estimate a $10 \%$ increase in fuel consumption to achieve the same power output. This would also increase total emissions of all constituents by $10 \%$ on a brake-specific basis ( $\mathrm{g}$ fuel/power $\times$ time; e.g., g/kWh). As the changes in fuel-specific emissions for $\mathrm{CO}, \mathrm{THC}$, and $\mathrm{NO}$ are substantially larger than $10 \%$, these constituents will be reduced (or increased, for NO) even after accounting for increased fuel consumption.

The higher bulk modulus of compressibility of biodiesel fuels can result in advanced fuel injection timing by as much as one to two crank-angle degrees [35, 36]. Additionally, changes in the spray and mixing behavior from oxygen content and fuel stoichiometry can increase the local temperature and heat release in the autoignition zone of the flame [27]. Both of these factors will result in a hotter combustion process as the biodiesel content of the fuel increases. In turn, this should result in more complete combustion, and a corresponding decrease in carbon monoxide and total hydrocarbon emissions, as seen in our results. The increased $\mathrm{NO}_{x}$ emissions are due to a combination of several different factors including advanced combustion and a hotter burn $[25,27,37]$. These conditions result more time at increased in-cylinder temperatures, which can promote increased $\mathrm{NO}_{x}$ production through the thermal NO mechanism.

Results from the ANOVA analysis of the generator emissions data showed that the fuel biodiesel content was significantly correlated to changes in emissions of all compounds except for $\mathrm{NO}_{2}$. Nitrogen dioxide formation and destruction reactions will both be influenced by biodieselinduced changes in combustion temperature and timing. Overall, we observed no consistent net effect due to the presence of biodiesel in the fuel. Variations in ambient temperature and humidity in the test cell were small during these tests (temperatures from $22-24^{\circ} \mathrm{C}$ and humidity from 55-60 grains/lb dry air) and did not impact the exhaust composition, while the exhaust temperature was significantly correlated with $\mathrm{CO}_{2}$ concentrations only. The measured exhaust temperature did decrease with higher biodiesel content, from a high of $106^{\circ} \mathrm{C}$ with number 2 diesel to a low of $98^{\circ} \mathrm{C}$ with the $\mathrm{B} 100$ fuel, a change directly related to the advanced injection timing. While biodiesel may burn hotter during the combustion process, this combustion occurs earlier in the expansion stroke of the engine. Since combustion is completed closer to top dead center, more work can be done by the engine (longer effective expansion stroke) before the exhaust valve opens and the cylinder walls see a larger temperature gradient for a longer time, promoting convective heat transfer. As a result, the exhaust temperature will decrease even though the peak combustion temperature is higher.

3.4. Mower Emissions. The effect of biodiesel blending on exhaust emissions of $\mathrm{CO}, \mathrm{THC}$, and $\mathrm{NO}_{x}$ was substantially different for the mower engine (Figure 3 ). While total hydrocarbon emissions did decrease with increasing biodiesel content, the change was not significant except for the B100 fuel. The maximum reduction of $25 \%$ from the $\mathrm{B} 5$ to the $\mathrm{B} 100$ fuel was also much smaller than the $52 \%$ reduction between the same two fuels in the generator studies. CO emissions showed no consistent pattern as biodiesel content increased, despite the typical linkage between these two partial combustion products.

$\mathrm{NO}_{x}$ emissions, by contrast, declined with increasing biodiesel content, with the greatest change between $50 \%$ and $100 \%$ biodiesel. This trend was very similar to that observed for total hydrocarbon emissions. NO was also a substantially higher fraction of total $\mathrm{NO}_{x}$ emissions from the mower, accounting for more than $75 \%$ of recorded $\mathrm{NO}_{x}$, as compared to $46-52 \%$ from the generator. The fuel-specific results from the mower study can also be adjusted to account for changes in biodiesel energy content, using the approach outlined above for the generator results. The decrease in both $\mathrm{NO}_{x}$ and THC concentrations was greater than the expected rate of increased fuel consumption for the B100 fuels, so emission reductions would occur for both compounds on a brake-specific basis as well. As with the generator engine, emissions may be more similar for the different fuel blends at higher operating speeds.

The ANOVA results for the mower study indicate that changes in fuel biodiesel content are significantly correlated with changes in emissions of all measured compounds, including $\mathrm{NO}_{2}$ (although the absolute changes in $\mathrm{NO}_{2}$ emissions were very small). Exhaust temperature was correlated with $\mathrm{CO}_{2}, \mathrm{NO}$, and $\mathrm{THC}$, but not with $\mathrm{CO}$ and $\mathrm{NO}_{2}$. The overall range of exhaust temperatures was smaller in the mower studies, with a maximum of $84^{\circ} \mathrm{C}$ during the $\mathrm{B} 5$ tests and a minimum of $81^{\circ} \mathrm{C}$ with $\mathrm{B} 100$. Ambient conditions also varied more during the mower tests, which were conducted outdoors. Temperatures during these tests ranged from $13-27^{\circ} \mathrm{C}$ and humidity from $23-73$ grains/lb dry air. Even so, ANOVA regression indicated no significant effect for ambient temperature on emission results. Humidity, however, was correlated with changes in $\mathrm{CO}_{2}, \mathrm{CO}$, and $\mathrm{NO}_{2}$ emissions. Changes in humidity can affect the fuel viscosity, which can in turn affect fuel injection and combustion patterns, resulting in fluctuations in $\mathrm{CO}$ and $\mathrm{CO}_{2}$ emissions. Increased humidity in the intake air has also been shown to decrease total $\mathrm{NO}_{x}$ production in multiple previous studies [38-40]. We used correction factors available for naturally aspirated off-road diesel engines [41] to adjust our $\mathrm{NO}_{x}$ results for the effects of humidity by calculating reference 


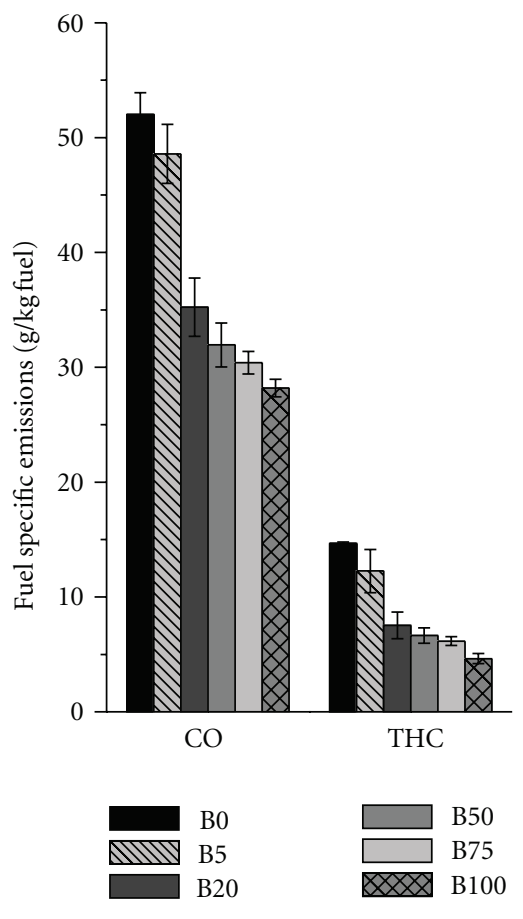

(a)

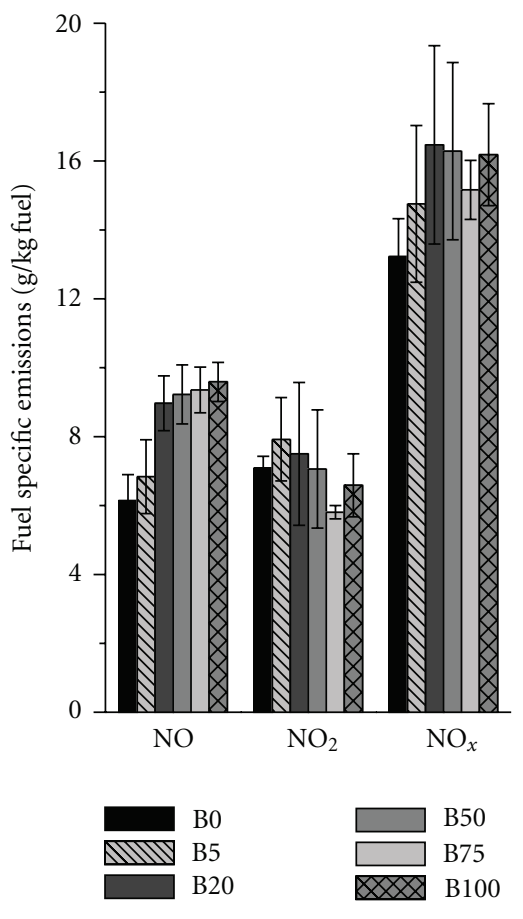

(b)

FIGURE 2: Gas-phase pollutant emissions from the generator engine (error bars indicate one standard deviation).

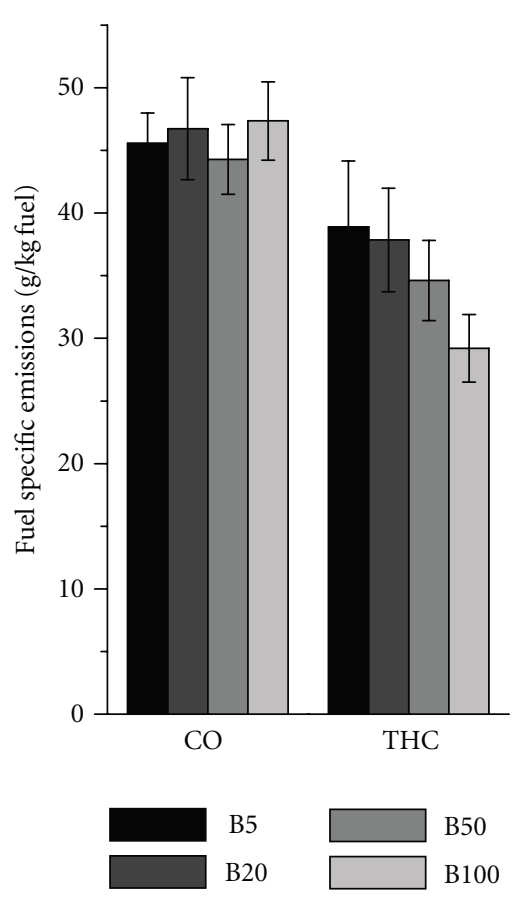

(a)

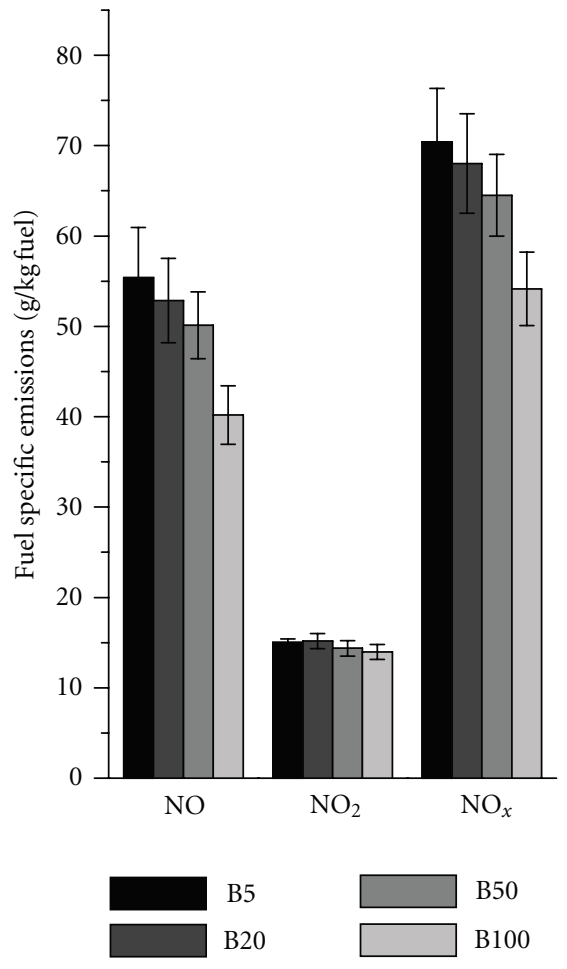

(b)

Figure 3: Gas-phase pollutant emissions from the mower engine (error bars indicate one standard deviation). 
$\mathrm{NO}_{x}$ values for each biodiesel content that were independent of ambient conditions. These adjusted data produced a similar trend in total $\mathrm{NO}_{x}$ emissions to the uncorrected results.

3.5. Comparing Biodiesel Effects on Exhaust Emissions. Fuelspecific emissions for all pollutant compounds except for $\mathrm{CO}$ were much higher from the mower in comparison to the generator at all biodiesel contents (Figures 2 and 3). Most notably, total $\mathrm{NO}_{x}$ concentrations were four to five times higher $(70 \mathrm{~g} / \mathrm{kg}$ fuel at $5 \%$ biodiesel content, compared to $15 \mathrm{~g} / \mathrm{kg}$ fuel from the generator), with the majority of this difference due to increases in NO. As noted above, trends for some compounds were also notably different as the biodiesel content increased. Table 5 provides the results of the Pearson correlation analysis between the significant influence factors (as determined by ANOVA analysis) and pollutant emissions levels. The major difference with respect to biodiesel content, the only factor significant for both engines, is with nitric oxide emissions, which decreased for the mower but increased for the generator as the biodiesel content increased. Additionally, $\mathrm{CO}$ emissions were only linearly correlated with biodiesel content for the generator.

The generator and front mower used in this experiment represent two different engine designs with respect to their fuel injection control. The US EPA adopted off-road diesel engine emissions regulations for engines under $50 \mathrm{hp}$ in 1996, after the front mower was put into service. The mower engine would therefore have had a fuel injection system optimized for performance at the expense of emission control. The generator, by contrast, was built in 2007 and therefore subject to Tier 2 emissions standards for engines under $11 \mathrm{hp}$ [29]. After off-road emissions standards were introduced, engine manufacturers began retarding the injection timing away from an optimum situation in order to reduce combustion temperatures and prevent the formation of $\mathrm{NO}_{x}$, a regulated compound. Moreover, increased levels of Exhaust Gas Recirculation (EGR) were introduced to act as a thermal diluent effectively reducing the combustion temperature. Hence, the generator has a port in the cylinder head that allows flow of exhaust gases from the exhaust manifold to the intake. This mower does not appear to have a dedicated EGR system (http://golftechs.us/Manuals/JD220dieselengine.pdf); since $\mathrm{NO}_{x}$ emission regulations did not exist at the time of its manufacture and EGR can decrease the fuel economy of the engine, there would be no reason to include such a system.

This difference in injection timing is the most likely source for the different responses of the two engines to increased biodiesel content. Retarding the combustion process will produce lower overall $\mathrm{NO}_{x}$ formation as combustion occurs more in the expansion stroke within a relatively "cooler" environment. $\mathrm{NO}_{2}$ is formed quickly from $\mathrm{NO}$ in a hot environment and can also be destroyed quickly, provided temperatures remain elevated. While $\mathrm{NO}_{2}$ can form rapidly in both engines, the flame quenches more easily in the generator, removing the necessary energy to convert $\mathrm{NO}_{2}$ back to NO. This accounts for the higher ratio of $\mathrm{NO}$ to $\mathrm{NO}_{2}$ in the mower at all fuel compositions.
TABLe 5: Pearson correlation coefficients for significant influence factors. Bold values show significant linear correlation at $95 \%$ confidence.

\begin{tabular}{lccccc}
\hline \multicolumn{7}{c}{$\mathrm{CO}_{2}$} & $\mathrm{CO}$ & $\mathrm{NO}$ & $\mathrm{NO}_{2}$ & THC \\
\hline \multicolumn{7}{c}{ Generator emissions } \\
\hline Biodiesel content & $-\mathbf{0 . 9 9 2}$ & $-\mathbf{0 . 8 6 6}$ & $\mathbf{0 . 7 3 8}$ & -0.369 & $-\mathbf{0 . 8 5 1}$ \\
\hline Mower emissions \\
\hline Biodiesel content & $-\mathbf{0 . 9 8 7}$ & 0.126 & $-\mathbf{0 . 7 9 1}$ & $-\mathbf{0 . 5 4 1}$ & $-\mathbf{0 . 6 8 0}$ \\
Exhaust temperature & 0.006 & $\mathbf{0 . 4 0 3}$ & -0.373 & $\mathbf{0 . 4 9 4}$ & $\mathbf{0 . 6 7 9}$ \\
Absolute humidity & -0.152 & $\mathbf{0 . 7 0 0}$ & -0.496 & $\mathbf{0 . 6 8 6}$ & $\mathbf{0 . 4 5 0}$ \\
\hline
\end{tabular}

Increasing the fuel biodiesel content should result in an accelerated fuel injection sequence in both the generator and mower engines, as discussed previously. The change in injection timing, however, may have a much less significant effect on the combustion profile for the older mower engine. When fuel injection timing is optimized for performance, heat release is maximized closer to top dead center, when the piston is moving relatively slowly. Hence, changing by a few crank-angle degrees will have a smaller effect on conditions within the cylinder. Under these conditions, the lower energy content of biodiesel may play a more important role in nitrogen oxide formation by reducing the in-cylinder temperature, resulting in the decreased $\mathrm{B} 100 \mathrm{NO}_{x}$ emissions observed in the front mower. The corresponding reduction in total hydrocarbon emissions in this fuel would thus be due primarily to the chemical composition of the WCO biodiesel, which allows for more complete fuel combustion even at slightly reduced temperatures. For the generator engine, by contrast, changing a few crank angle degrees for combustion can have a large effect on exhaust emissions, as pressures and temperatures are changing more dramatically during the expansion stroke (the piston accelerates from top dead center to the middle of the expansion stroke). Further investigation of this behavior would require collection of in-cylinder pressure and temperature data, which was not available for this study.

\section{Conclusions}

While the physical properties of the six WCO biodiesel batches produced by the KU Biodiesel Initiative showed little variation, the FAME content of the four samples collected in 2010 included less saturated compounds while consisting of longer chain compounds than the 2009 samples. Elemental analysis of the fuel $\mathrm{H}: \mathrm{C}$ ratio and oxygen content were generally in line with the FAME analysis, indicating that the GC-MS technique provided a good characterization of the overall fuel, despite the presence of some unquantifiable fragments. The small differences in fuel batch-to-batch variability suggest that changes in the WCO feedstock makeup will have relatively little effect on the resulting fuel.

Increased WCO biodiesel content in the fuel lowered emissions of total hydrocarbons in both engines under idle conditions, with greater reductions at lower biodiesel content in the generator engine. These decreases are consistent 
with similar results from other studies of waste cooking oil biodiesel and most likely result from compositional differences between biodiesel and petroleum diesel, particularly the higher oxygen level and lower aromatic content. The relationship between biodiesel content and $\mathrm{CO}$ and $\mathrm{NO}_{x}$ emissions, by contrast, varied substantially between the two engines. The generator results follow typical patterns in the literature for biodiesel, with decreased $\mathrm{CO}$ and increased $\mathrm{NO}_{x}$ production. In the front mower, however, increased biodiesel content resulted in decreased $\mathrm{NO}_{x}$ emissions and had virtually no effect on $\mathrm{CO}$. This difference is likely related to differences in fuel injection timing strategies between the two engines.

These results indicate that the effects of biodiesel use in nonroad engines on emission profiles may depend greatly on the fuel injection strategy used, which in turn will be related to the age of the engine. In the United States, off-road vehicles and equipment less than 10-15 years old (depending on the specific engine class) are subject to the U.S. EPA's tiered emissions standards for off-road engines. As a result, these engines will generally employ delayed fuel injection timing to control $\mathrm{NO}_{x}$ emissions, along with EGR, and may see increased $\mathrm{NO}_{x}$ and reduced hydrocarbon emissions due to biodiesel use. Engines built before this time, however, were not subject to emission regulations, and are more likely to be optimized for engine performance. Many stationary diesel engines currently in use will also fall into this category, as regulations for these engines apply only to new engines built since 2007.

Our results suggest that the use of biodiesel blends in these older off-road and stationary engines may actually result in the reduction of both $\mathrm{NO}_{x}$ and total hydrocarbon emissions levels. As our studies were conducted only under idle conditions and for one type of biodiesel fuel, they must be considered preliminary, and more testing on older off-road diesel engines should be conducted to determine the full nature and extent of this effect. If this pattern is observed for a broader range of conditions, however, then the use of biodiesel blends in preemissions control off-road engines could have a substantially positive effect on exhaust emissions of gas-phase pollutants.

\section{Acknowledgments}

The authors thank Pavan Ilipilla of the University of Kansas Environmental Engineering program for assistance in data collection. This research was funded by the University of Kansas, Transportation Research Institute from Grant no DT0S59-06-G-00047, provided by the U.S. Department of Transportation Research and Innovative Technology Administration.

\section{References}

[1] A. Murugesan, C. Umarani, R. Subramanian, and N. Nedunchezhian, "Bio-diesel as an alternative fuel for diesel enginesa review," Renewable and Sustainable Energy Reviews, vol. 13, no. 3, pp. 653-662, 2009.
[2] A. C. Pinto, L. L. N. Guarieiro, M. J. C. Rezende et al., "Biodiesel: an overview," Journal of the Brazilian Chemical Society, vol. 16, no. 6B, pp. 1313-1330, 2005.

[3] A. K. Agarwal, "Biofuels (alcohols and biodiesel) applications as fuels for internal combustion engines," Progress in Energy and Combustion Science, vol. 33, no. 3, pp. 233-271, 2007.

[4] G. Knothe, J. Van Garpen, and J. Krahl, The Biodiesel Handbook, AOCS Press, Champaign, , Ill, USA, 2005.

[5] N. M. Ribeiro, A. C. Pinto, C. M. Quintella et al., "The role of additives for diesel and diesel blended (ethanol or biodiesel) fuels: a review," Energy and Fuels, vol. 21, no. 4, pp. 2433-2445, 2007.

[6] M. Lapuerta, O. Armas, and J. Rodríguez-Fernández, "Effect of biodiesel fuels on diesel engine emissions," Progress in Energy and Combustion Science, vol. 34, no. 2, pp. 198-223, 2008.

[7] United States Environmental Protection Agency, "A comprehensive analysis of biodiesel impacts on exhaust emissions," Tech. Rep. EPA 420-P-02-001, Assessment and Standard Division, Office of Transportation and Air Quality, USEPA, Washington, DC, USA, 2002.

[8] Y. Zhang, M. A. Dubé, D. D. McLean, and M. Kates, "Biodiesel production from waste cooking oil: 2. Economic assessment and sensitivity analysis," Bioresource Technology, vol. 90, no. 3, pp. 229-240, 2003.

[9] A. Radich, "Biodiesel performance, costs and uses, EIA Analysis Report, Energy Information Agency," US Department of Energy, http://www.eia.doe.gov/oiaf/analysispaper/biodiesel/, 2004.

[10] V. E. Eidman, "Renewable liquid fuels: current situation and prospects," Choices, vol. 21, no. 1, pp. 15-19, 2006.

[11] A. Demirbas, "Relationships derived from physical properties of vegetable oil and biodiesel fuels," Fuel, vol. 87, no. 8-9, pp. 1743-1748, 2008.

[12] M. Cetinkaya and F. Karaosmanoğlu, "A new application area for used cooking oil originated biodiesel: generators," Energy and Fuels, vol. 19, no. 2, pp. 645-652, 2005.

[13] M. S. Graboski and R. L. McCormick, "Combustion of fat and vegetable oil derived fuels in diesel engines," Progress in Energy and Combustion Science, vol. 24, no. 2, pp. 125-164, 1998.

[14] T. Issariyakul, M. G. Kulkarni, A. K. Dalai, and N. N. Bakhshi, "Production of biodiesel from waste fryer grease using mixed methanol/ethanol system," Fuel Processing Technology, vol. 88, no. 5, pp. 429-436, 2007.

[15] M. Mittelbach and S. Gangl, "Long storage stability of biodiesel made from rapeseed and used frying oil," Journal of the American Oil Chemists' Society, vol. 78, no. 6, pp. 573-577, 2001.

[16] G. Knothe and K. R. Steidley, "A comparison of used cooking oils: a very heterogeneous feedstock for biodiesel," Bioresource Technology, vol. 100, no. 23, pp. 5796-5801, 2009.

[17] Z. Utlu and M. S. Koçak, "The effect of biodiesel fuel obtained from waste frying oil on direct injection diesel engine performance and exhaust emissions," Renewable Energy, vol. 33, no. 8, pp. 1936-1941, 2008.

[18] M. E. Gonzalez Gomez, R. Howard-Hildige, J. J. Leahy, T. O'Reilly, B. Supple, and M. Malone, "Emission and performance characteristics of a 2 litre Toyota diesel van operating on esterified waste cooking oil and mineral diesel fuel," Environmental Monitoring and Assessment, vol. 65, no. 1-2, pp. 13-20, 2000.

[19] M. S. Koçak, E. Ileri, and Z. Utlu, "Experimental study of emission parameters of biodiesel fuels obtained from canola, hazelnut, and waste cooking oils," Energy and Fuels, vol. 21, no. 6, pp. 3622-3626, 2007. 
[20] M. P. Dorado, E. Ballesteros, J. M. Arnal, J. Gómez, and F. J. López, "Exhaust emissions from a diesel engine fueled with transesterified waste olive oil," Fuel, vol. 82, no. 11, pp. 1311 1315, 2003.

[21] Y. Di, C. S. Cheung, and Z. Huang, "Experimental investigation on regulated and unregulated emissions of a diesel engine fueled with ultra-low sulfur diesel fuel blended with biodiesel from waste cooking oil," Science of the Total Environment, vol. 407, no. 2, pp. 835-846, 2009.

[22] Y. F. Lin, Y. P. G. Wu, and C. T. Chang, "Combustion characteristics of waste-oil produced biodiesel/diesel fuel blends," Fuel, vol. 86, no. 12-13, pp. 1772-1780, 2007.

[23] D. Y. C. Leung, "Development of a clean biodiesel fuel in Hong Kong using recycled oil," Water, Air, and Soil Pollution, vol. 130, no. 1-4, pp. 277-282, 2001.

[24] C. S. Lee, S. W. Park, and S. I. Kwon, "An experimental study on the atomization and combustion characteristics of biodiesel-blended fuels," Energy and Fuels, vol. 19, no. 5, pp. 22012208, 2005.

[25] R. L. McCormick, M. S. Graboski, T. L. Alleman, A. M. Herring, and K. S. Tyson, "Impact of biodiesel source material and chemical structure on emissions of criteria pollutants from a heavy-duty engine," Environmental Science and Technology, vol. 35, no. 9, pp. 1742-1747, 2001.

[26] P. Benjumea, J. R. Agudelo, and A. F. Agudelo, "Effect of the degree of unsaturation of biodiesel fuels on engine performance, combustion characteristics, and emissions," Energy and Fuels, vol. 25, no. 1, pp. 77-85, 2011.

[27] C. J. Mueller, A. L. Boehman, and G. C. Martin, "An experimental investigation of the origin of increased $\mathrm{NO}_{x}$ emissions when fueling a heavy-duty compression-ignition engine with soy biodiesel," SAE International Journal of Fuels and Lubricants, vol. 2, no. 1, pp. 789-816, 2009.

[28] E. Cecrle, C. Depcik, A. Duncan et al., "Investigation of the effects of biodiesel feedstock on the performance and emissions of a single-cylinder diesel engine," Energy \& Fuels, vol. 26, no. 4, pp. 2331-2341, 2012.

[29] United States Environmental Protection Agency, "Control of Emissions of Air Pollution from Nonroad Diesel Engines: Final Rule," 40 CFR Parts 9, 86 and 89. Environmental Protection Agency, Federal Register, 1996.

[30] N. Pekula, B. Kuritz, J. Hearne, A. J. Marchese, and R. P. Hesketh, "The effect of ambient temperature, humidity, and engine speed on idling emissions from heavy-duty diesel trucks," SAE Paper 2003-01-0290, 2003.

[31] L. A. Graham, N. Muegge, J. Rostkowski, D. Ayyad, and D. Karman, "Development of real world representative test cycles and measured emission rates for selected off-road spark ignited engines," SAE Paper 2006-32-0093, 2006.

[32] D. K. Carder, M. Gautam, G. J. Thompson, and R. A. Barnett, "Determination of in-use brake-specific emission from offroad equipment powered by mechanically controlled diesel engines," SAE Paper 2002-01-1756, 2002.

[33] SEMTECH-DS User Manual, Revision 1. 11, Sensors, Saline, Mich, USA, 2006.

[34] A. Demirbaş, "Biodiesel fuels from vegetable oils via catalytic and non-catalytic supercritical alcohol transesterifications and other methods: a survey," Energy Conversion and Management, vol. 44, no. 13, pp. 2093-2109, 2003.

[35] A. L. Boehman, D. Morris, J. Szybist, and E. Esen, "The impact of the bulk modulus of diesel fuels on fuel injection timing," Energy and Fuels, vol. 18, no. 6, pp. 1877-1882, 2004.

[36] R. L. McCormick, A. Williams, J. Ireland, M. Brimhall, and R. R. Hayes, "Effects of biodiesel blends on vehicle emissions,"
Tech. Rep. NREL/MP-540-40544, National Renewable Energy Laboratory, Golden, Colo, USA, 2006.

[37] G. A. Ban-Weiss, J. Y. Chen, B. A. Buchholz, and R. W. Dibble, "A numerical investigation into the anomalous slight $\mathrm{NO}_{x}$ increase when burning biodiesel; a new (old) theory," Fuel Processing Technology, vol. 88, no. 7, pp. 659-667, 2007.

[38] W. J. Brown, S. A. Gendernalik, R. V. Kerley, and F. J. Marsee, "Effects of engine intake-air moisture on exhaust emissions," SAE Paper 700107, 1970.

[39] M. J. Manos, J. W. Bozek, and T. A. Huls, "Effect of laboratory ambient conditions on exhaust emissions," SAE Paper 720124, 1972.

[40] S. R. Krause, "Effect of engine intake-air humidity, temperature, and presure on exhaust emissions," SAE Paper 710835, 1971.

[41] L. G. Dodge, T. J. Callahan, and T. W. Ryan, "Humidity and temperature correction factors for $\mathrm{NO}_{x}$ emissions from diesel engines: final report," SwRI Project 03. 30. 10. 06599, Southwest Research Institute, San Antonio, Tex, USA, 2003. 

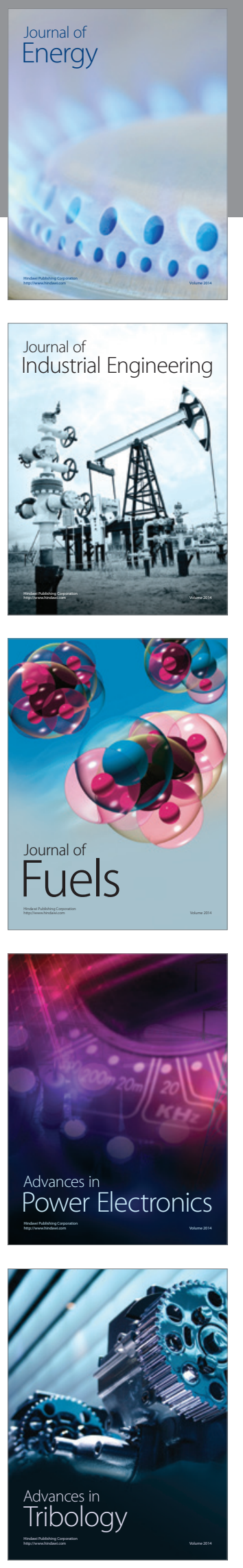
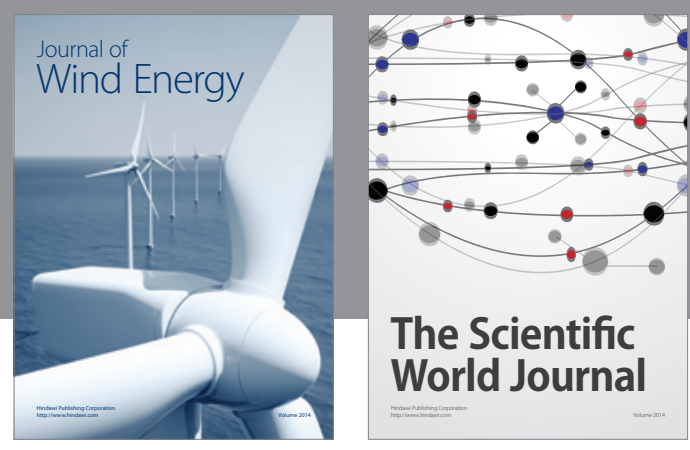

The Scientific World Journal

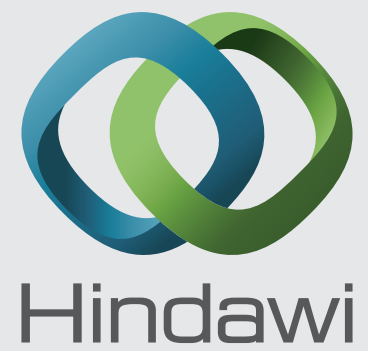

Submit your manuscripts at http://www.hindawi.com
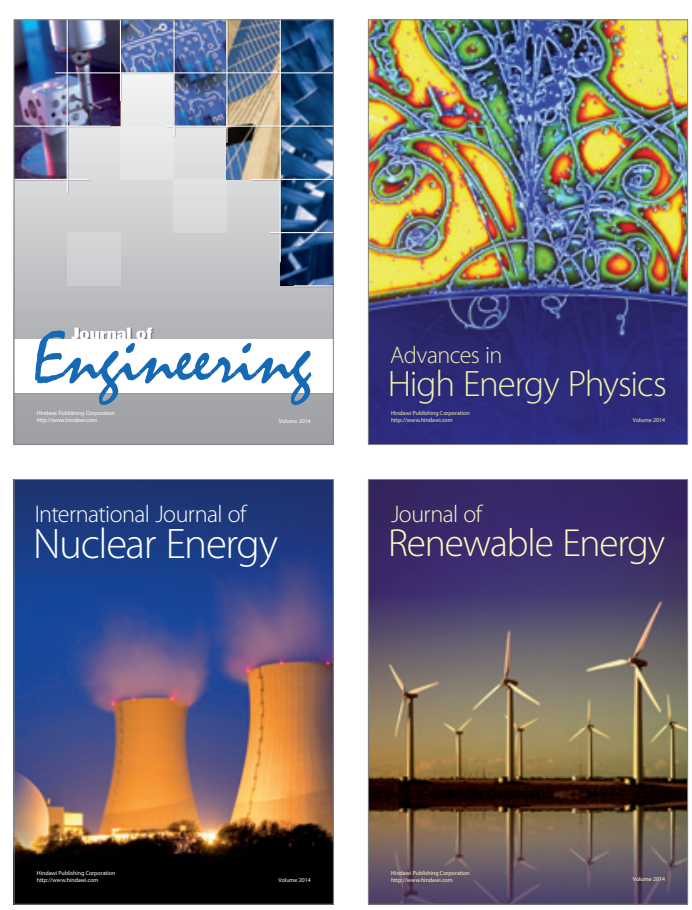

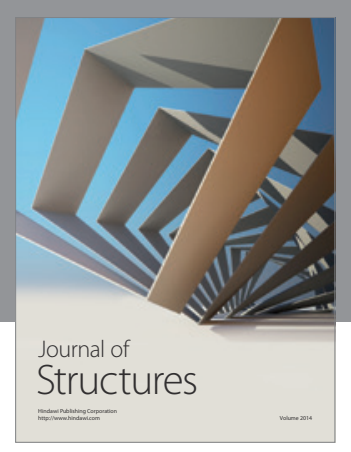

Rotating
Mechinery
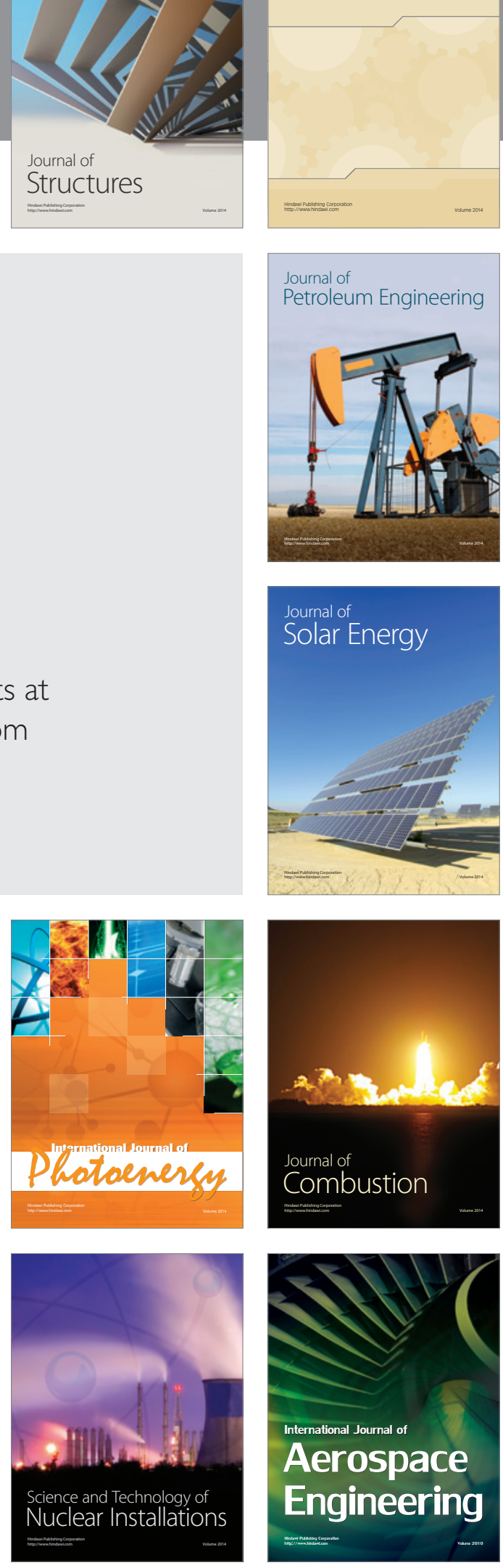